\title{
Research on Business English Flipped Classroom Teaching Mode Based on Network Resource Sharing Platform
}

\author{
Xingchao Liu \\ Shandong Agriculture and Engineering University, Shandong, Jinan, 250100
}

Keywords: network resources; Business English; flipped classroom

\begin{abstract}
With the acceleration of the process of global integration, countries in the world have become increasingly frequent in economic, cultural and diplomatic relations. In this social context, high-quality business English talents are increasingly favored by the market. How to cultivate business English talents that meet market needs has become an urgent problem for many undergraduate and higher vocational colleges. The paper takes the flipped classroom teaching mode in business English as the main research object, analyzes the advantages of combining business English with flipped classroom teaching mode under the network resource sharing platform, and seriously discusses how to correctly construct the flipped classroom teaching mode in business English teaching.
\end{abstract}

\section{Introduction}

The widespread use of the Internet has greatly accelerated the process of educational informationization and promoted the sound development of education. If the Internet technology and the course are deeply integrated, applying the flip classroom teaching mode to business English teaching can effectively improve the teaching efficiency and the learning effect of the students.

\section{The Characteristics and Current Status of Business English Teaching}

Business English teaching is very different from general English teaching. It not only pays attention to the teaching of students' English knowledge, but also teaches students the management philosophy of Western countries, the working psychology of workers in Western countries, and even the daily life of people in Western countries. Lifestyle so that they can communicate and collaborate well with them in future jobs. As China's business contacts with other countries around the world become more frequent, complex and high-quality business English talents are enthusiastically favored by the market, and many undergraduate colleges and higher vocational colleges that serve as such talent delivery bases should actively improve their teaching. Mode, strive to cultivate talents that meet the needs of society.

At present, many undergraduate colleges and higher vocational colleges in China have established business English majors. However, due to various factors, the teaching effect is not satisfactory. Many business English majors have poor theoretical knowledge and are more capable in language use. Weak, can not meet the market demand for business English talents. There are two main reasons for this situation. First, the teaching model is backward. Nowadays, many undergraduate colleges and higher vocational colleges still use the traditional teaching mode in business English teaching, that is, mainly teachers and textbooks. The result of this kind of teaching mode is often that the teacher instills knowledge into the students, and the students can only accept them passively. Although it seems that the teaching process arranged by the school is completed, the teaching results are completely confused. This is mainly because this teaching mode does not highlight the student's dominant position in learning, which has hampered the students' enthusiasm for learning. Therefore, the learning effect is naturally not ideal. Second, the teacher strength is poor. Many business English teachers in undergraduate colleges and higher vocational colleges are directly enrolled in the school after the English major. They lack relevant business work experience and it is difficult to grasp the key points and difficulties of business English. Although these 
teachers are well-versed in teaching basic English, once it comes to professional business English, it is often difficult to find a breakthrough in teaching, and it is impossible to realize the digging of business English teaching from shallow to deep.

\section{The Connotation of Flipped Classroom Teaching Mode}

The flip classroom is translated from "Flipped Classroom" or "Inverted Classroom". To put it simply, flipping teaching means that students learn knowledge first, and then teachers explain knowledge. This is the first explanation with the teachers in traditional teaching. Then students are doing the opposite of knowledge learning. Flipping the classroom teaching mode turns the "introduction and after-school links" in traditional teaching into "pre-course links and intra-course links". Specifically, the teacher uploads the knowledge points to be learned in the classroom to the network in the form of images or PPT. Students need to study and study before they go to class. In the classroom, teachers mainly help students to deepen the knowledge of previous learning through exercises and other teaching activities [1].

\section{The Advantages of Combining Business English with Flipped Classroom Teaching Mode}

Compared with the traditional business English teaching, the use of the flip classroom teaching mode in business English can make full use of high-quality teaching resources. The biggest advantage of flipping the classroom teaching mode is that relying on the Internet, students can enjoy high-quality and rich teaching resources on the network platform, understand the curriculum dynamics related to business English, and master more theoretical knowledge of business English. The carrier function of the network platform is very powerful. Many business English courses in the world's top universities, English speeches by famous people, and teaching videos and teaching courseware of some business English training institutions can be found on the network platform. Students only need to move in front of the computer. You can start enjoying your own resources with your fingers.

It is very different from general English. Business English pays more attention to the ability of students to communicate well on a business topic. In order to ensure the improvement of students' speaking ability, in the business English class, it should be guaranteed that there is a certain time for students to conduct oral and oral training, instead of teaching traditional students to dumb English, just like traditional English teaching. In the business English teaching, the flip classroom teaching mode is adopted, so that students can fully understand the knowledge points they will learn before the beginning of the class and have a certain accumulation in the language material, so there will be more in the classroom. Time is used for oral communication between teachers and students or between students, so as to effectively improve students' language communication ability and cultivate students' good business English sense.

In the traditional business English teaching process, teachers usually put the main time and energy on the explanation of the knowledge points, while the students act as a writer to record the teacher's explanations. Under this circumstance, the student's status as the protagonist of learning is neglected, and the students' participation in learning is not strong, so the students' interest in learning is not good, and the learning effect naturally declines. The flipping classroom teaching mode focuses on the student's leading role in learning, which greatly increases the sense of participation of students. Students need to prepare for the knowledge points before starting the class. After the class starts, they need to communicate with teachers and classmates about a certain knowledge point. This will effectively improve students' self-learning ability.

The core of flipping classroom teaching mode is people-oriented, student-oriented, and students are the core and key of classroom teaching. The use of flip classroom teaching mode in business English teaching can break the limitations of previous classroom teaching, allowing students to have more time and opportunity to communicate and improve their language skills. At the same time, in the discussion and analysis of the group, the teamwork ability of the students will also be strengthened. 


\section{Construction of Business English Flipped Classroom Teaching Mode Based on Network Resource Sharing Platform}

To realize the application of the flip classroom teaching mode in business English teaching, we must first ensure that the school has a certain network infrastructure and that students have access to network information such as computers and mobile phones. Nowadays, with the continuous development of science and technology and the widespread popularity of the Internet, almost all undergraduate colleges and higher vocational colleges have realized this precondition, which also provides a good opportunity for the application of flipping classroom teaching mode in business English teaching. .

The design of the teaching process in the business English flipping classroom teaching mode based on the network resource sharing platform can be divided into three steps. The first step is to develop a corresponding instructional design under the guidance of the teaching objectives. The second step is that before the class begins, the teacher publishes the knowledge points to be taught in the form of images or PPT, so that the students can learn by themselves. At this time, in addition to learning the teaching resources of the teachers uploading the network, the students can also on the network. Other resources related to the teaching content are studied. The third step is to explain the blind spots of students' learning in the classroom, to help students improve in a targeted manner, and also to carry out various forms of teaching activities to enhance students' interest in learning and ensure the students' leading role in learning.

Applying the flip classroom teaching model to business English teaching, the role of the teacher has also undergone major changes. In the past business English teaching, the teacher is the leader of the classroom, the compulsory indoctrinator of the classroom knowledge, and completely controls the development of the classroom and the learning of the students' knowledge. Now, teachers are the organizers and guides of classroom activities, more like students' close friends than high-ranking teachers.

\section{Conclusion}

Flipping the classroom as a relatively new teaching mode, its timely appearance just caters to the needs of business English teaching for the network resource sharing platform. Many practices have shown that applying the flip classroom teaching mode to business English teaching can effectively improve the results of teaching and learning.

\section{References}

[1] Duan Chunyan. Design of Business English "Flipping Classroom” Teaching Model Based on Network Learning Resource Sharing Platform [J]. China Training, 2016(16): 151-152.

[2] Hui Zhaoyang. Construction of Business English Reading Teaching Model Based on "Flip"[J]. Heilongjiang Education (Higher Education Research and Evaluation), 2016(04): 29-30.

[3] Qiu Min. Innovation of Business English Translation Teaching Based on Flipping Classroom in "Internet +" Era [J]. Education and Occupation, 2016(15): 94-97.

[4] Li Rong, Li Shuguang. Application of Performance Evaluation in Business English Flipping Classroom [J]. Software Guide (Education Technology), 2017, 16(09): 16-18.

[5] Gao Wenyu. Feasibility Study of Flip Class Mode in Business English Courses in Colleges and Universities [J]. Journal of Heilongjiang College of Education, 2017, 36(10): 142-144. 